\title{
Black Mothers and Black Boats: Queer, Indigenous, and Afro-Brazilian Intersections in Ney Matogrosso’s “Mãe preta (Barco negro)"
}

DANIEL DA SILVA

Columbia University

\begin{abstract}
As part of his 1975 solo debut album, Água do céu-pássaro, Ney Matogrosso recorded a cover of "Barco negro," a Portuguese fado made famous by Amália Rodrigues and based on an earlier Brazilian song, "Mãe-preta," written by Caco Velho and Piratini and recorded by Os Tocantins in 1943. Matogrosso conflates the two versions, titling the track, "Mãe preta (Barco negro)." This article marks Matogrosso's recording as an iteration of transgender voice and locates - in his performance and album artwork - queer, indigenous, and Afro-Brazilian intersections that rework the mãe preta figure central to Brazil's foundational narrative. Making use of Hortense Spiller's theorization of the trans-Atlantic slave trade as "body-theft," I argue that Matogrosso's referents and trans voice reembody the Luso-Afro-Brazilian black mother in ways that unsettle Lusotropicalism and haunt Portuguese nationalist tropes.
\end{abstract}

Keywords: Transgender, voice, fado, Hortense Spillers, Lusotropicalism

Ney Matogrosso released his critically acclaimed debut solo album Água do céupássaro in 1975, having left the chart-topping Brazilian rock band Secos e 
Molhados after two years as its lead vocalist. Secos e Molhados was famous for its progressive, glam, and folk-rock music, and for band members appearing in full-face makeup and provocative costuming. More than crafty tunes and playful stage presence, however, Matogrosso's countertenor voice was the band's most notable attribute. As a countertenor possessing a voice type and vocal range approaching and at times overlapping the female soprano, Matogrosso reveled in its ambiguous nature, augmenting it with androgynous performances that underscored the homoerotic undertones of some of the band's songs. ${ }^{1}$ His voice was a siren call, transgressively reaching up into the affective registers of female repertoires, sometimes accentuated by his flamboyant styling and at other times in stark contrast to his often naked torso exposing a hairy chest, suggesting a more virile masculine archetype even as his voice sung out in feminine tones. Throughout his many successes, from band vocalist to solo artist, and in his current role today as a celebrated legend of música popular brasileira, Matogrosso's voice has been both praised and derided, winning over many fans but not without its critics. While as band member in Secos e Molhados his voice could be seemingly read as part of the band's eccentric showmanship, in context with other band antics, Matogrosso's solo debut put his voice, body and creative direction center stage.

Beyond fans and critics, Matogrosso's countertenor voice type has at times also provoked unintended identification as a transgender voice. Ney de Souza Pereira, as Matogrosso is known offstage, has played with this power, claiming that he enjoyed using his provocative singing voice to upend conventions of heteronormative gender that can be found replicated in music and performance conventions of voice types and genre repertoires. Throughout his career, Matogrosso claims, "A minha voz foi o grande impacto, porque as pessoas se perguntavam se era homem ou mulher" (Vaz 123). While he may have reveled in the confusion that his voice caused, Matogrosso does not claim a transgender identity. On the contrary, he has said in interviews that he enjoys being a cisgender man: "Gosto de ser homem, sempre mostrei o peito cabeludo e nunca quis ser mulher na minha manifestação artística; procurei apenas checar o limite

\footnotetext{
${ }^{1}$ Secos e Molhados' first hit, “O vira” (1973), about a man turning into a werewolf, plays with turning as a reference to sexuality and same-sex cruising while also mimicking the turns of a traditional Portuguese folkloric dance, while "Sangue latino" (1973) refigures the masculinist and oversexed tropes of Latin culture through Matogrosso's feminine voice and performance.
} 
imposto entre o masculino e o feminino. E acho que o público sempre percebeu que era um homem fazendo tudo aquilo" (Vaz 87). He insists that his public and fans are well aware that he is a cisgender man. Yet, some critics took issue with Matogrosso sounding like a woman, suggesting that his countertenor voice type could transgress his cisgender male identity. One telling detraction lasted approximately two years, during which he was not mentioned by name in Jornal do Brasil. Editor Walter Fontoura admitted to avoiding Matogrosso in print, saying, "Não gostava do cantor e das músicas. Para o meu gosto não se tratava de um artista. Posso estar certo ou errado, mas não reconhecia nele méritos para sair no Caderno B. Detestava ouvir uma voz de mulher num homem. [...] Continuo não gostando" (Vaz 87). Fontoura makes his case for censoring Matogrosso's name from his publication by dismissing the artist and his music as unworthy of coverage in the arts section and giving his personal distaste as the reason for this refusal. He betrays a more sinister motivation, however, by revealing that he detested hearing the voice of a woman coming from a man.

Fontoura's transphobic censorship of Matogrosso from the pages of his newspaper allows for a productive consideration of Matogrosso's voice as a trans formation of Brazilian popular music repertoire. Regardless of Matogrosso's assertion that his male cisgender identity was always evident, even as he argues that he often bared his hairy chest to play with queer notions of masculinity, he is not in control of how his voice is received. For Fontoura, Matogrosso's voice is a woman's voice. It is an unintended identification of Matogrosso's voice as a site of gender transgression. It also marks a trans voice that gives voice to other women and reveals occluded histories of oppression within mythologized Brazilian discourses of race and nation. Notably, on his debut release, among a cacophony of sounds, songs, and referents, Matogrosso chose to record a version of the iconic Portuguese fado "Barco negro," first made famous by fado diva Amália Rodrigues (Amália). However, Matogrosso named his version as "Mãe preta (Barco negro)," recalling the forgotten history of this fado as the Brazilian song "Mãe preta," written by Piratini and Caco Velho and recorded by Conjunto Os Tocantins (1943), which told a story of the Brazilian mãe preta, the black mother, made to nurture the family of her enslaver while bearing silent witness to the violence enacted on her loved ones.

The following sections consider how Matogrosso's voice, in configuration with the album production, invoke the cries of the mãe preta that haunt the 
original Brazilian lyrics to show how, as a trans voice, Matogrosso rematerializes the mãe preta in a particular Luso-Afro-Brazilian intersection of race, gender, and sexuality. The history of the Afro-Brazilian mãe preta is one of gendered and racial violence erased and remade as a place of honor in Freyrean mythology of masters and slaves. Gilberto Freyre's mãe preta emerges in his foundational work Casa-grade e senzala, first published in 1933, as the body that nurtures his notion of a racial democracy. Matogrosso's recording of "Mãe preta (Barco negro)," however, rematerializes her as a voice of suffering and sobbing even as he sings Amália's fado with lyrics of forlorn widows and Portuguese men lost at sea. Beyond the song's titular transgression, Matogrosso's voice sounds the cries and unearths the violent history of the mãe preta. Through his recording, she emerges as an audible specter that haunts the Portuguese fado "Barco negro," while his body, represented in album art, performs a queer, mythical amalgam of Brazilian cultural iconography.

\section{Dude Sings Like a Lady: Countertenor Trans Formations}

Água do céu-pássaro offers an audiovisual intervention in the gendered and racialized tropes of Brazilian cultural heritage. Through body and voice, Matogrosso materializes and critiques an array of Brazilian cultural and nationalist discourses. Christopher Dunn describes Matogrosso's costuming and posing in photos used for the album's artwork as "ambiguously gendered, combining corporeal signs of femininity with the robust virility of a cave man," a move that suggests for Dunn affinities with the modernist antropofagia movement of the 1920s (Contracultura 193). In photos with Matogrosso posing, looming, crouching, stretching, and in mid-dance, he appears as an assemblage of man, myth, and animal that points to indigenous mythology, Afro-Brazilian folklore, and European colonialism. These references seep out on the album's front cover (Figure 1) through horsehair, feathers, horns, and talismans that adorn his body. He wears a headdress that is both the beak of a monstrous bird and a battle helmet, while the sparse dark hair of his chest and abdomen are set against the whiteness of his skin. The album's name gestures toward indigenous mythology and Afro-Brazilian folklore through its hyphenated formation, describing a bird as water from the sky, invoking Brazil's vast territory, flora, and fauna. To underscore the coded symbolism imbedded in the work, a 
hieroglyph meant to represent the album adorns the back cover, resembling the constellation of the Southern Cross bent out of shape (Figure 1).

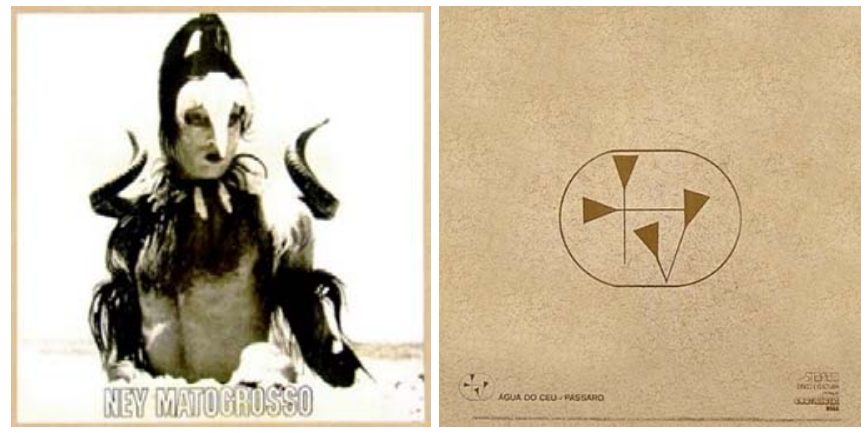

Figure 1: The front and back cover of Água do céu-pássaro

Beyond the album's artwork, Matogrosso's voice and the album's overall audio production form a discordant soundscape as a terrain through which the mythical creature moves. Songs bleed into each other without dead air or pauses to separate them. Rather, the sounds of wildlife, wind, and water take up the transitions from one track to the next. "Homem de Neanderthal" opens the album with a fade-in of bird squawks, monkey calls, and the hissing of a forest, giving way to thunderclaps, rain, and blaring horns. Finally, Matogrosso's voice breaks through the cacophony in a screeching introduction to a song about a primitive man gathering snails by the riverside. His howl turns sultry, however, as the verses declare, "Eu vivo apenas com meus próprios meios; eu vivo em penas com meus sentimentos." These lines are at once liberating, seductive, and vulnerable. The penas that adorn Matogrosso's body in feathers on the album artwork are rendered as markers of sentimentality and sexuality through his play on words with apenas, suggesting a simplicity that is undermined by the many meanings of pena in Portuguese, which can be feather, or punishment, suffering, pity, and sadness, among other things. Penas in this song may refer to the feathers of his costume as well as allude to feathers as sexual fetish, or in the nuanced meanings of penas, be read as a defiant declaration of an arduous self-sufficiency, or perhaps a confession of loneliness, while also pressing at suggestions of sorrow and shame, pity and punishment, regret and compassion. Matogrosso's voice marks every turn of phrase with provocative implications. 
Throughout the album, Matogrosso's songs, voice, costuming, and audiovisual production act together as an assemblage of queer, indigenous, and Afro-Brazilian referents that refigure the sounds of Brazilian popular music along culturally critical fault lines, not the least of which is the gender transgression that sounds out through Matogrosso's voice. Throughout his now decades-long career, Matogrosso's voice has been a constant point of recognition and contention. César Braga-Pinto identifies Matogrosso as one of many "transgendered voices [that] have been present in Brazilian music for many decades" (189), while Dunn argues that Matogrosso was "the supreme avatar of [a] transgendered gay sensibility" during the "countercultural ethos" of the latesixties and early-seventies popular culture and music in Brazil (Brutality Garden 172). Both Dunn and Braga-Pinto mark Matogrosso's vocal range as transgressing the normative voice types for male singers. As a countertenor, Matogrosso's feminine voice is situated in a history of transgressive voice and body modification for performance and also subjugation, conquest, and aesthetic purposes. Castrati singers, as one example, were young boys castrated before the onset of puberty to keep their voices high and unchanged, utilized throughout Europe from the mid-sixteenth century in liturgical music and in the seventeenth and eighteenth centuries in opera. A much longer history of castration as subjugation and mutilation for the purpose of creating singing eunuchs predates Renaissance traditions (Tougher; Sherr). Joke Dame argues that castrati and other transgressive voices in music and performance have been associated with androgyny, hermaphroditism, sexual ambiguity, femininity, and may convey a sense of the angelic, the weak, and the nonhuman. However, when the male body from which the voice emits is considered, Dame shows how these performers are also often considered "powerful and strong," with a voice that "penetrates the accompaniment $[\ldots]$ with tremendous staying power," suggesting the "castrato's virility, the phallus, has been displaced into his voice" (142-43). Matogrosso plays with the tension between weakness and virility in his debut, moving from soft to shrill, transitioning from sensual high notes to howling yells that climb up through a gritty midrange, often in the same song.

Andrew Anastasia suggests that voices, beyond speech articulation, have "something to say about the body's age, sex, race, nationality, or ability. How others make sense of a trans* voice, especially relative to one's physical appearance, can provoke great anxiety or pleasure. The voice $[. .$.$] can pierce us$ 
in unexpected ways, turning us toward (or away from) another in an acoustic and affective register. [...] One can never predict how our voices will be heard, and unpredictable reception is part of the voice's value" (262). Anastasia employs the asterisk to mark trans as myriad unfolding gender positions and identifications, some possibly unintended. Jack Halberstam's thinking of trans through the asterisk helps to understand the provocation of Matogrosso's voice, where trans* speaks to "unfolding categories of being organized around but not confined to forms of gender variance [...] the asterisk modifies the meaning of transitivity by refusing to situate transition in relation to a destination, a final form, a specific shape, or an established configuration of desire and identity" (Trans*4). As an intervention in the differing and overlapping iterations of trans, the asterisk works to dislodge gender from binary anchor points while keeping the desire for and power of recognition in play. It keeps trans in motion as a social and intimate process rather than destination.

Voices are also in motion as they travel toward others, moving across space and time, to be heard and listened to, to be recognized and counted. Moreover, voices may also impede motion, denounce, or oppress, in some instances, and may also unintentionally reveal, tell, and accuse, in other instances. Once sounded out, the voice is unpredictable in is reception. It is also often a point of anxiety for transgender people looking to pass as a gender that may not be associated with their vocal range or type, and may require hormone therapy or physical therapy to modify its pitch. The voice then may sound out unintended forms of gender recognition, provoking affective responses and interactions apart from the trans* or cisgender body. Halberstam argues that trans "describes not simply an identity but a relation between people, within a community, or within intimate bonds [important] to people who want to place themselves in the way of particular forms of recognition" (In a Queer Time and Place 85). These forms of recognition are made knowable by a series of markers and ways of being socially construed and adjudicated. The unpredictability of vocal reception may not allow for an intended form of recognition, and may provoke an unintended recognition altogether. As Fontoura's transphobic derision of Matogrosso's voice shows, though Matogrosso has not put himself in the way of a trans* identity, his voice type and range provoke an affective response that infers a move across genders and puts into play a charged interaction between Matogrosso and his audience, between his countertenor voice and the affective reception that his voice incites. 
While his voice type moves across gendered conventions of vocal range, Matogrosso further refuses destination through his singing by transitioning from the howls of the opening track to sensual moans and sorrowful murmurs; traveling up into female soprano territory and returning to a lower range with ease. Similarly, the album tracks move across particular Brazilian spaces and time, touching upon diverse histories and discourses of race, gender, and sexuality. From the opening "Homem de Neanderthal," suggesting a primitive and queer point of origin, the album moves to the sitars of "O corsário" and "Idade de ouro" that may be suspected to invoke Portuguese colonialism. "Cubanakan" and "América do Sul" gesture toward Brazil's singular position in a Spanish-speaking Latin America. "Açucar candy" has explicit references to oral sex, with explosions of sweet confections that climax in an aural orgasm, queering tropes of Brazilian hypersexuality and turning the sugar cane of its past slave plantation economy into an orgasmic phallus. "Bodas" brings together references of canons, war, and wedding feasts in a broad critique of violence that ties it to heteronormative rituals of marriage and family, a critique that is also an implicit takedown of the military dictatorship in place at the time of the album's release. The exuberance of "Açucar candy" and its orgasmic release serves as a counterpoint to "Bodas," and to the dampened cultural and social atmosphere of 1970s Brazil under authoritarian rule.

Nestled among those tracks is "Mãe preta (Barco negro)," a remake of the Portuguese fado "Barco negro" with lyrics by David Mourão-Ferreira. The fado was made famous by Portuguese fadista Amália Rodrigues, who recorded and performed it as herself for the French film Les amants du Tage (dir. Henri Verneuil, 1955). That fado's melody, however, was first written as the Brazilian song "Mãe preta," composed by Caco Velho (Matheus Nunes) and Piratini (António Amábile), and recorded with substantially different lyrics by Conjunto Tocantins in 1943. The original "Mãe preta" offers a picture of life under slavery in Brazil through multipart harmonies, rhythmic guitars, and a soft samba beat singing the life of the mãe preta, the black mother or mammie, an enslaved African or Afro-Brazilian domestic servant, wet nurse, nanny, and much more. The lyrics tell of mãe preta caring lovingly for her master's children in the big house while wiping away tears as her own loved one is beaten in the slave quarters. It is a startling narrative of the physical and emotional violence of slavery visited specifically upon women, separated from their own partners and 
families and made to nurture their oppressors: "Era assim que mãe preta fazia / Criava todo branco com muita alegria / Enquanto na senzala seu bem apanhava / Mãe preta mais uma lágrima enxugava / Mãe preta! mãe preta / Enquanto a chibata batia em seu amor / Mãe preta embalava o filho branco do sinhô."

The song was recorded several times by different singers, all of whom maintained the melody and original lyrics. In 1955, it reappeared in Portugal as Amália Rodrigues's "Barco negro," with the same melody as "Mãe preta," though now reconfigured as a brooding Portuguese fado, which by the midtwentieth century was cementing its place as the nation's signature musical genre. $^{2}$ Poet David Mourão-Ferreira provided a new narrative through his lyrics, one of fate, love, and loss, bearing the marks of Portuguese nationalist discourse built upon a mythology of men taking to the sea. "Barco negro" has since become one of Amália's and one of the genre's most recognizable fados. MourãoFerreira's version dislocates the song from the Brazilian plantation's big house and slave quarters and anchors it on Portuguese shores, as a young woman strewn on a sandy beach waits for a love that is lost at sea, surrounded by older widows assuring her of his demise. The lyrics recall the centrality of the sea to Portuguese nationalist tropes, and characterize the nation and its saudade of past glories as a disappeared seafaring man ever desired by the pious and faithful woman awaiting his return, all enacted through fado's fatalistic bent. What remains of the original Brazilian composition beyond the melody might be heard in the rhythmic batucada lightly tapped out on the body of the guitar as introduction. Yet, the tapping is morose and far removed from the more consistent and gentle rhythm of the original tune.

The resonating taps on the guitar's hollow body that mark Amália's version of the song are admittedly a rare instance of any actual percussion as part of a fado. They recall not only the melody's past as a Brazilian song but also the ways

\footnotetext{
2 David Ferreira, son of David Mourão-Ferreira, gives a history of the song's different versions, from the first cover by Maria da Conceição, with a pace and mood much more akin to Portuguese fado in Portugal, either in 1952 or in 1954, to other versions recorded in Brazil by Ester Abreu and Edson Lopes. The song was popular and traveled in different versions from Portugal to Angola, then still under Portuguese colonial rule, as well as back to Brazil. Ferreira writes that in 1954-55, his father, who had been writing poems for Amália's fados, was solicited by the French filmmakers of Les amants du Tage to write a fado for Amália to sing in their film. Ferreira does not explain why his father chose the melody of "Mãe preta" but does refute an often-repeated claim that the Estado Novo censored the original lyrics, thereby requiring Ferreira's new lyrics, by pointing out that Angolan band Duo Ouro Negro recorded a version of "Mãe preta" in 1961.
} 
that fado as a genre developed in part through Afro-Brazilian songs and dances (Holton 2006; Nery 2012), which traveled to Lisbon through processes of remembering, forgetting and reinventing cultural practices that were provoked by the large-scale and violent displacement of people around the Atlantic rim, from Africa to the Americas, the Caribbean, and Europe (Roach 1996). Paul Gilroy also underscores the "structures of feeling, producing, communicating, and remembering" (3) found in this Atlantic transit as processes of what he calls the Black Atlantic. Fado, a peripheral practice of Lisbon's marginal people and places in the mid-nineteenth century, was codified, regulated, and gained national stature during the twentieth century under the Portuguese Estado Novo. It has long lost its dance repertoire and any obvious ties to an Afro-Brazilian past. Its current and most recognizable form is made up of a Portuguese guitar, a Spanish or classic guitar, and a vocalist. It has become Portugal's national genre as an expression of fatalist sentiment projected as a particularly Portuguese condition. If the instrumentation of fado has forgotten its roots, however, fado vocal stylings may still make room for the expression of desire and conditions of life on society's margins, particularly in the form of fado's feminine repertoire, one that Matogrosso takes up when he records Amália's fado. Matogrosso conjoins the song title "Mãe preta" parenthetically with "Barco negro," reconnecting the fado to its Brazilian roots as a lament and expression of Afro-Brazilian life. Tauntingly, Matogrosso names the forgotten tune but does not otherwise veer away from "Barco negro," unmooring Mourão-Ferreira's poem from Portugal while suspending the full recontextualization of "Mãe preta." Rather, Matogrosso's high countertenor sings the gendered and impassioned role of the female fadista, faithful to Amália's fado in vocal melody and to MourãoFerreira's lyrics, while the music and rhythm offer a more progressive folk-rock instrumentation and percussive update.

A crescendo of howling wind leads into an upbeat tempo and a mix of instrumentation, from rhythmic guitars and piano to the Afro-Brazilian berimbau, while the familiar melody of the fado is plucked out on guitars. Matogrosso sings as the fado's protagonist, a woman who awakens on the sandy beach as her lover sets off to sea. Suddenly, she has a vision of a black boat, dangerous rocks, and a cross appearing as a frightening omen that tragedy has struck. Older women on the beach confirm as much when they assure her that her man will not return. The fado's climax are two forceful lines where the protagonist offers a powerful 
Silva

rebuke of these women as crazy. The fado ends in quiet resignation, as she continues alone without her lover's return but sensing his presence all around her: "Vi depois, numa rocha, uma cruz / E o teu barco negro dançava na luz / Vi teu braço acenando, entre as velas já soltas / Dizem as velhas da praia, que não voltas / São loucas! / São loucas! / Eu sei, meu amor / Que nem chegaste a partir / Pois tudo, em meu redor / Me diz que estás sempre comigo." Amália marks this submission to fate with sung sighs and quiet hums. Matogrosso, however, lets his voice unfold into sobs, breaking not only with the original composition but with fado conventions altogether. While Amália's recording showcases her trademark glissandos and melismas, now conventional techniques of deploying vocal drama in fado practice through dramatic slides of the voice and singing single syllables over a range of notes, she does not weep. Lila Ellen Gray notes how fadistas often "hover on the break of sob" but that "actual crying by the singer would threaten the rupture of form, loss of control, making it impossible to continue to sing" (41-42). Matogrosso, however, delivers on the threat. $\mathrm{He}$ refuses to relinquish the melodrama. As the guitars and percussion fade out, Matogrosso's voice reverberates as a distraught woman weeping, pulling us out of the fado altogether and holding us in the anguish of her cries.

Matogrosso's emotionally intense ending prompted music critic and historian José Ramos Tinhorão to write, "Ney ficava chorando igual que uma mulherzinha" (Vaz 87). Once again, Matogrosso's voice is marked as a site of gender transition. Tinhorão's use of the diminutive of mulher to underscore his description suggests it was meant as an implicitly negative critique, implying an aversion to Matogrosso's cries and sobs at the end of the song, and revealing the unsettling affect of his voice and particularly of his voice in this context. For the entirety of the song, Matogrosso is a woman, inhabiting the role of the protagonist, who is gendered female in Mourão-Ferreira's original lyrics for Amália. Matogrosso sings the gendered grammar without changes. Tinhorão, however, points to the crying and sobbing woman as the point of transgression, the turning point, the site of excess, overtly exaggerated and implicitly false. Portuguese dictionaries tend to present mulherzinha as a pejorative term that marks a vulgar and off-putting performance of womanhood or femininity, such as a young girl acting out in a womanly fashion or overly dramatic displays of emotion; the Michaelis Dicionário Brasileiro da Língua Portuguesa claims that the word may also be used to describe an effeminate man. These definitions are 
conflated in Tinhorão's criticism, marking Matogrosso's womanly weeping as a move not only across genders but towards the vulgar and aberrant. It is a moment in which Matogrosso goes beyond the fadista, where his weeping reverberates across time and through the different iterations of this melody. It is a transgression that lingers, and that drags out into the open the cries of another woman long occluded by "Barco negro," by fado mythology, and by Brazilian Lusotropicalist discourses of race and nation.

Matogrosso's cries may be heard as the cries of the mãe preta lamented in the original lyrics by Piratini and Caco Velho, which describe how she quickly dried her eyes of tears that are erased altogether by the song's transformation into a fado. Matogrosso's weeping brings forth the tears over which the original mãe preta was not allowed to linger. His voice amplifies and drags out her sobs. Rather than insipid, his dramatic ending materializes a history of violence and subjugation that forces a confrontation with the deep-rooted Lusotropicalist mythology of the benevolent Portuguese colonialism of Brazil's past, its contemporary exceptionalism as a racial democracy rooted in Freyre's foundational text Casa-grande e senzala, and the role of the enslaved African woman in the foundation of Brazilian society. The conflation of the two songs and Matogrosso's feminine cries invoke the spectral black mother and the particular gendered violence visited on black women in the process of building Luso-Afro-Brazilian society. Further, the black boat as fated omen turns into a phantom reference to slave ships_-black boats of a different kind, with hulls full of African bodies, haunting Portuguese nationalist tropes of seafaring adventures.

\section{Black Mothers and Black Boats}

Freyre's Casa-grande e senzala founded a national mythology of Brazil as a racial democracy propagated by a benevolent if lascivious Portuguese colonizer and built upon the figure of the mãe preta, who looms in Freyre's narrative as the heart of the master's big house and its intimate labors. Freyre's work refigures Portuguese colonization as a promiscuous enterprise (118), suggesting a colonialism meted out in mixed-race sexual trysts and marriages by lustful overlords lacking white women. He offers this sexual violence as a place of compromise, where the distance between master and slave is mitigated by sex and bonds of kinship. It is the mãe preta, however, who must walk the few steps 
from the slave quarters to the big house as enslaved laborer and hypersexualized partner, and whose body physically nurtures the family of her enslavers. Jossianna Arroyo argues that "mães pretas or black nannies played the most important role in the 'Brazilianization' of culture" and describes mãe preta "as a symbolic mother of the Brazilian nation, as well as a border figure that makes miscegenation possible" (59).

In Freyre's narrative, the mãe preta occupies a privileged space within the patriarchal family:

Quanto às mães-pretas, referem as tradições o lugar verdadeiramente de honra que ficavam ocupando no seio das famílias patriarcais. Alforriadas, arredondavam-se quase sempre em pretalhonas enormes. Negras a quem se faziam todas as vontades: os meninos tomavam-lhe a bênção; os escravos tratavam-nas de senhoras; os boleeiros andavam com elas de carro. E dia de festa, quem as visse anchas e enganjentas entre os brancos de casa, havia de supô-las senhoras bem-nascidas; nunca ex-escravas vindas da senzala. (592)

He focuses on their bodily girth as a sign of that privilege, claiming as evidence of their esteemed status the ways their bodies would round out into enormous black figures. His focus on their enormous blackness is a vulgar rending of the black mother. Pretalhona does not refer simply to a large, black woman but rather to a vulgar version of this woman; it is an immenseness of black material as vulgar excess. This fixation on large, black women as vulgar aberrations belies the fundamental importance Freyre assigns to them in his Lusotropicalist love triangle. Around these women's aberrant blackness, enormous and unrefined, an entire society coalesces in the formation of the Brazilian nation. Freyre dislocates the mãe preta from any history prior to her role in the big house, with no mention of captivity, violence, or the black mother's kin. She is an icon around which children gather for blessings, a respected elder paraded around, a diva whose every wish is granted. The myth starts to unravel, however, as he lists the qualifications to be chosen for such an intimate role and all the responsibilities that were put upon her: 
É natural que essa promoção de indivíduos da senzala à casa grande, para o serviço doméstico mais fino, se fizesse atendendo a qualidades físicas e morais; e não à toa e desleixadamente. A negra ou mulata para dar de mamar a nhonhô, para niná-lo, preparar-lhe a comida e o banho morno, cuidar-lhe da roupa, contar-lhe histórias, às vezes para substituir-lhe a própria mãe-é natural que fosse escolhida dentre as melhores escravas da senzala. Dentre as mais limpas, mais bonitas, mais fortes. Dentre as menos boçais e as mais ladinas - como então se dizia para distinguir as negras já cristianizadas e abrasileiradas, das vindas há pouco da África; ou mais renitentes no seu africanismo. (592)

The image of little ones gathering around the mãe preta seems to suggest that she was integrated into bonds of intimacy and ties of kinship, part of a familial structure, while Freyre's description assigns a gendered role to the enslaved mãe preta as mother, mistress, nanny, and nurse. However, mãe preta in this account is not a privileged member of the family, but a figure that is scrutinized for her beauty, her cleanliness, her strength - suggesting that her duties within the house went beyond that of wet nurse or nanny, to include sexual, social, educational, and manual labor as well. Further, the bonds of kinship that Freyre points to were not her own but entirely those of the master and at the master's will, at risk of being ruptured and interrupted at any moment. Rather than a place of privilege, what Freyre's description belies and Matogrosso's weeping exclaims outright is the distressing role of the mãe preta who takes on both manual and intimate labor for her oppressor.

Hortense Spillers presents gender as a central vector of violence under slavery. ${ }^{3}$ Spillers argues that the act of enslaving African people degendered them, dismembered lines of kinship, and disorganized social and cultural life, which was then reinvented and renamed according to the slave master's will in the Americas. African women, Spillers argues, became "'Peaches' and 'Brown Sugar,' 'Sapphire' and 'Earth Mother,' 'Aunty,' 'Granny,' God's 'Holy Fool,' a

\footnotetext{
${ }^{3}$ Spillers is responding to Patrick Moynihan's report “The Negro Family" (1969). Published in the United States, Moynihan's report called out strong black women and African American matriarchy as the main problem facing black men and black families in the US, who would find it hard to thrive in the patriarchal traditions of the American — read white — family.
} 
'Miss Ebony First,' or 'Black Woman at the Podium'" (65). To this list, one can add the mãe preta, in affinity with "Aunty" and "Granny" (through the antecedent figure of the black mammy on southern US plantations), but with its own particular place within the Luso-Afro-Brazilian formation of black women. These names are representative of what Spillers calls "a locus of confounded identities, a meeting ground of investments and privations in the national treasury of rhetorical wealth." Spillers argues that, as a black woman, the nation "needs me, and if I were not here, I would have to be invented" (65). In a similar fashion, Freyre's early twentieth-century fable of Brazilian racial democracy, the genesis of which is the relation between the big house and slave quarters, requires the mãe preta, inventing her as an enormous black orb around which Brazilian society supposedly coalesced.

Spillers's assessment of the violence enacted on African bodies and their social and intimate relationalities offers a productive undoing of Freyre's tale of promiscuous benevolence. She presents a stark narrative of New World encounter, framing it as a "human sequence written in blood, [which] represents for its African and indigenous peoples a scene of actual mutilation, dismemberment, and exile" (67):

Their New-World, diasporic plight marked a theft of the body-a willful and violent [...] severing of the captive body from its motive will, its active desire. Under these conditions, we lose at least gender difference in the outcome, and the female body and the male body become a territory of cultural and political maneuver, not at all gender-related, gender-specific. But this body, at least from the point of view of the captive community, focuses a private and particular space, at which point of convergence biological, sexual, social, cultural, linguistic, ritualistic, and psychological fortunes join. (67)

Making a distinction between body and flesh, and noting that heteronormative gender roles between men and women develop in and require domestic and desiring contexts, Spillers argues that for these African people, victims of body theft, gender and domestic and desiring roles of any kind are disrupted and made impossible until reinvented according to the master's will, at the mercy of the 
state's design. Spillers notes this violence did not discriminate, and both men and women enslaved were ungendered, their flesh torn apart, lines of kinship severed, erased, violently stolen, and forcibly beaten out.

Notably, and as an unintended counterpoint to Freyre's romance of racial miscegenation, Spillers references a fifteenth-century Portuguese narrative of racist encounter with Africans in Gomes Eanes de Zurara's Crónica do descubrimento e conquista da Guiné pelos portugueses. Spillers writes: "Three genetic distinctions are available to the Portuguese eye, all along the riffs of melanin in the skin: in a field of captives, some of the observed are 'white enough, fair to look upon, and well-proportioned.' Others are less 'white like mulattoes,' and still others 'black as Ethiops, and so ugly"' (70). ${ }^{4}$ These reflections reveal a hierarchy not dissimilar to Freyre's telling of an old adage, "Branca para casar, mulata para f[oder], negra para trabalhar" (104). The offputting proverb, intended for men, reveals how women are categorized by their different skin tone as markers of their utility and reverberates as strikingly similar to Freyre's notes on the criteria for the selection of mães pretas. Spillers notes that Zurara's narrative is also about "males looking at other males. [...] Few places in these excerpts carve out a distinct female space [...] no heed is paid to relations, as fathers are separated from sons, husbands from wives, brothers from sisters and brothers, mothers from children-male and female" (70).

By her blackness alone, then, according to the racist hierarchy first noted in the fifteenth century and echoed by Freyre in the twentieth, the mãe preta is a worker rather than an honored member of the family, even if her labors are intimate. As evidence for the gender violence and racism exposed in Spillers's observations, Zurara's account, and Piratini and Caco Velho's "Mãe preta," five hundred years after the violent start of the trans-Atlantic slave trade, Freyre still makes no reference to the black mother's own kin. Her violent displacement from African shores and her estrangement and separation from the senzala are seen as privilege, but in actuality the moving of mãe preta from the senzala to the casagrande is a violence that invents her gender role according to the colonizer's

\footnotetext{
${ }^{4}$ Josiah Blackmore reads Zurara's symbolic and spatial appropriation of Africa through an interpretation of hues of African skin: "By metonymically racializing African land through the colors of its inhabitants, Zurara and others attempt to establish otherness as an inert fact of nature waiting to be revealed through the hermeneutic act of writing" (Moorings 31). Skin color, then, serves as both pragmatic and racist distinction of productivity for the Portuguese in Zurara's account, and as literary device for its chronicler.
} 
need. The description of a whip beating mãe preta's loved ones in the original lyrics by Piratini and Caco Velho may underscore the violence against her kin as the cause of her tears. Yet, what Matogrosso's anguishing cries and Spillers's research make clear is the full spectrum of gendered and physical violence visited upon black women in this Luso-Afro-Brazilian formation. The whip also came down on mãe preta's flesh, and her move from the slave quarters to the big house was a second body theft, a second dismemberment of gender, sex, and ties of kinship.

By misnaming "Barco negro" as "Mãe preta" and breaking out of the song to cry unconsolably, Matogrosso makes space for the black woman of this violent history, for the loss and mourning put upon mãe preta to be heard. Though Spillers is defining an "American grammar" that addresses the history of the United States, the "American" descriptor applies equally to South America when the perspective is that of the enslaved and oppressed who were forcibly moved throughout the Circum-Atlantic, and not of the particularities of colonial histories and empires told from the top down. Her charge that "the violent formation of a modern African consciousness" in response to "the Atlantic Slave Trade [...] interrupted hundreds of years of black African culture" (68) is also justly put to Luso-Afro-Brazilian history. Yet, the crying black mother may mark an intimacy that flourishes despite violent oppression. Mãe preta cries for herself and for others, and Spillers reminds us that even the enslaved may "maintain the powerful ties of sympathy that bind blood relations in a network of feeling, of continuity" (74).

Unexpectedly, it is through Matogrosso's cover of the Portuguese fado, rather than the original "Mãe preta" song, that we may put Spillers's charge to work as part of a reckoning with Luso-Afro-Brazilian history. Matogrosso's voice type provokes a consideration of transitive vocal registers that reach back to castration, often used as subjugation and as part of enslavement. In such contexts, this kind of body modification resonated as the mark of captivity, of dismemberment, of body theft. In this way, Matogrosso's weeping is a material invocation of mãe preta that resonates with histories of enslavement and violence, even as it may mark points of transgender anxiety, affirmation, and identification. Moreover, as the title "Barco negro" describes, the ominous black boat seen in a vision is refigured through the black mother's cries into a specter of Portuguese boats that carried captive black bodies across the Atlantic. Here, 
too, Spillers offers insight into the gender violence enacted through enslavement, where men, women, and children were allotted different-sized compartments on these ships, not to accommodate gender but erasing their sexual differences outright as a matter of space planning to exploit every inch of the hull: "Under these conditions, one is neither female, nor male, as both subjects are taken into 'account' as quantities" (72). Rather than Portuguese sailors lost at sea, Spillers asserts that those truly lost in the middle passage were the African people enslaved: "Removed from the indigenous land and culture, and not yet 'American' either, these captive persons, without names that their captors would recognize, were in movement across the Atlantic, but they were also nowhere at all [...] culturally 'unmade,' thrown in the midst of a figurative darkness that 'exposed' their destinies to an unknown course" (72). Thus, the black boat of Mourão-Ferreira's fado may yet represent slave ships occluded by revisionist Portuguese tropes and histories of voyages, discoveries, and seafaring European adventurers. Through Matogrosso's voice, in song and in sobs, the black mother of Freyrean lore may cry openly, mourning boats of blackness, dismembered black bodies, and interrupted desires, lost at sea only to be reinvented in LusoAfro-Brazilian fictions upon which contemporary nations and subjectivities are built.

\section{Queer Cacophony}

As a gay man with a transgender voice type, materializing the ghosts of black mothers and black boats, Matogrosso recalls Dame's underscoring of the male body from which the countertenor/trans voice emerges. His body is a vector of queer masculinity that, nevertheless, butts up against the tropes of indigeneity present in his costuming. In album artwork, in performances to promote the album's release, and in a video for the album track "América do Sul," Matogrosso is a confusion of man, myth, and beast. His presence hovers over the entirety of the album as an ambiguous reference to Brazilian indigenous mythology, and as such gestures abstractly at the history of Brazil's indigenous peoples, precarious as a political entity but wholly subsumed into the Brazilian national imaginary. From José Alencar's Iracema (1865) to Mário de Andrade's Macunaíma (1928), and as part of Freyre's racial miscegenation, indigeneity has been dispersed from the indigenous tribes and communities on the ground into a 
Silva

broad Brazilian iconography and cultural heritage that muddles, confounds, and refigures the many different indigenous peoples and traditions with one another and with Afro-Brazilian cultural practices - a different kind of body theft that in many ways continues still. Andrade's Macunaíma is an example of such a rhapsody of images, histories, and languages - a cacophony of cultural references reduced and flattened out as representative of a Brazilian way of being.

Matogrosso also transits through this muddled indigeneity. Through his fantastical avatar, his voice, and the anxiety his vocal type provoked in some, he makes accomplices out of his detractors, whose criticisms harken back to early European accounts detailing anxiety over the queer sexual practices of indigenous people, anxieties that betrayed piqued curiosity if not explicit interest and desire. João Silvério Trevisan notes how Europeans first arriving in Brazil perceived the "nefarious sin" of sodomy as raging through the indigenous population like a contagion (4-5), where gender roles were not clearly defined according to the European/Western patriarchal binary of male muscularity and female fragility, where there were not just men and women but also "menwomen" and "women-men," men who gave themselves freely and openly to sex with other men, young boys engaged in sexual play or at work in delicate tasks of weaving, and other "incidences of same-sex relations" that both shocked and fascinated Europeans and marked life as scandalous below the equator (7). Matogrosso's portrayal of queer indigeneity resurfaces these occluded sexualities and anxieties. His feathers and headdress loom as delicate works and markers of vulnerability, virility, seduction, and aberration. If these perversions were meant to be straightened out through Freyre's Lusotropicalism, erasing the indigenous queer man and feminizing him as subjugated and cuckolded, with Portuguese colonizer set up as sexual, political, and moral authority through whose exploits a racial democracy emerges, Matogrosso rematerializes the aberrant and drowns out the fable in a saturation of sound and subjectivities.

Matogrosso offers a disorienting embodiment and audiovisual assemblage akin to Jodi Byrd's conceptual use of cacophony as "the competing representations of diasporic arrivals and native lived experiences" that encounter each other within discursive, cultural, and political spheres (14). Through Matogrosso, thus, Afro-Brazilian, queer, and indigenous resonances and complaints emerge not as monolithic narrative but as colliding voices, bodies, 
and desires. Byrd argues for cacophony as a methodology of reading the (post)colonial conditions of "contradictorily hegemonic and horizontal struggles [...] discordant incommensurabilities and misapplied representations that try to pass themselves off as coherent, consistent, and real" (53). As intervention, Byrd suggests cacophony can make audible the "multiple colonial experiences grounded not only in race but gender, indigeneity, conquest, and sexuality as well" (53). In affinity with Michael Rothberg's identification of multidirectional memory that is "subject to ongoing negotiation, cross-referencing, and borrowing; as productive and not privative" (Rothberg 3), Byrd offers a critical cacophony as a "multidirectionality [that] creates the possibility for memory and resistance to forge alliances across historical and cultural experiences in opposition to the competitions upon which colonialism relies" (53). Through his voice, performance, and the taking up of discordant forms, Matogrosso suggests a potent incommensurability of those subjectivities onto which empire, nation, and normativity have visited violence and erasure.

Matogrosso's dissonance is the undoing of consensus from under which howls, orgasms, and weeping vie for return. Moving through queer, indigenous, and Luso-Afro-Brazilian references marks a relation between these points of subjectivity even as they are made strange in their cacophonous juxtaposition, recalling Eve Sedgwick's definition of queerness as "relational, and strange," and more so as "multiply transitive [...] antiseparatist as it is antiassimilationist" (xii). Matogrosso's "Mãe preta (Barco negro)" and his debut album as a whole move in multiple ways as a cacophonous reply to Luso-Afro-Brazilian mythology, an atavistic rendering that conflates Brazilian and Portuguese histories as accomplices in violent and whitewashed monolithic nationalisms. The silencing of mãe preta's cries has had long-standing consequences for LusoAfro-Brazilian racial tensions and notions of blackness, and in many ways continues in systemic and institutional violence and racism. Matogrosso's body as vector for his voice underscores the affinities of mãe preta's oppression with the historical stigmatization of nonnormative bodies, genders, and sexualities. In the album's squawking wildlife, howling queer voice, crying black mother, and haunting black boats, Lusotropicalist myths collapse, sobs linger, and tensions remain potently unresolved. 


\section{Works Cited}

Alencar, José de. Iracema. Garnier, 1865.

Anastasia, Andrew. "Voice." Transgender Studies Quarterly, vol. 1, no. 1-2, 2014, pp. 262-63.

Andrade, Mário de. Macunaíma. Eugenio Cupolo, 1928.

Arroyo, Jossianna. "Brazilian Homoerotics: Cultural Subjectivity and Representation in the Fiction of Gilberto Freyre." Lusosex: Gender and Sexuality in the Portuguese-Speaking World, edited by Susan Canty Quinlan and Fernando Arenas, U of Minnesota P, 2002, pp. 57-83.

Blackmore, Josiah. Moorings: Portuguese Expansion and the Writing of Africa. U of Minnesota P, 2009.

Braga-Pinto, César. "Supermen and Chiquita Bacana's Daughters." Lusosex: Gender and Sexuality in the Portuguese-Speaking World, edited by Susan Canty Quinlan and Fernando Arenas, U of Minnesota P, 2002, pp. 187-207.

Byrd, Jodi A. The Transit of Empire: Indigenous Critiques of Colonialism. U of Minnesota P, 2011.

Conceição, Maria da. Mãe preta. Odeon, 1954.

Dame, Joke. "Unveiled Voices: Sexual Difference and the Castrato." Queering the Pitch: The New Gay and Lesbian Musicology, edited by Philip Brett et al. Taylor \& Francis, 2006, pp. 139-54.

Dunn, Christopher. Brutality Garden: Tropicália and the Emergence of a Brazilian Counterculture. U of North Carolina P, 2001.

-. Contracultura: Alternative Arts and Social Transformation in Authoritarian Brazil. U of North Carolina P, 2016.

Ferreira, David. "Canção do sambista Caco Velho foi 'reimportada' para o Brasil." Valor, 12 Sept. 2017, www.valor.com.br/cultura/5116154 /cancao-do-sambista-caco-velho-foi-reimportada-para-o-brasil.

Freyre, Gilberto. Casa-grande e senzala. 1933. José Olympio, 1952.

Gilroy, Paul. The Black Atlantic: Modernity and Double Consciousness. Harvard UP, 1993.

Gray, Lila Ellen. Fado Resounding. Duke UP, 2013.

Halberstam, J. Jack. In a Queer Time and Place. New York UP, 2005.

-. Trans*. U of California P, 2018.

Holton, Kimberly. "Fado Historiography: Old Myths and New Frontiers." P, vol. 
0, 2006, pp. 1-17.

Matogrosso, Ney. Água do céu-pássaro. Warner Music Brasil, 1975.

—. "América do Sul." YouTube, Paulo César, 16 Dec. 2008, www.youtube .com/watch? $\mathrm{v}=$ FkuflcS5fPw.

Moynihan, Daniel P. "The Negro Family: The Case for National Action." U.S. Department of Labor, 1965. The Moynihan Report and the Politics of Controversy: A Transaction Social Science and Public Policy Report, edited by Lee Rainwater and William L. Yancey, Massachusetts Institute of Technology P, 1967, pp. 47-94.

"Mulherzinha." Michaelis dicionário brasileiro da língua portuguesa. Editora Melhoramentos, 2019, michaelis.uol.com.br/modern-portugues/busca/ portugues-brasileiro/mulherzinha.

Nery, Rui Vieira. A History of Portuguese Fado. Imprensa Nacional-Casa da Moeda, 2012.

Roach, Joseph. Cities of the Dead: Circum-Atlantic Performance. Columbia UP, 1996.

Rodrigues, Amália. Amália. Columbia, 1955.

Rothberg, Michael. Multidirectional Memory: Remembering the Holocaust in the Age of Decolonization. Stanford UP, 2009.

Secos e Molhados. Secos e molhados. Warner Music Brasil, 1973.

Sedgwick, Eve. Tendencies. Duke UP, 1993.

Sherr, Richard. "Guglielmo Gonzaga and the Castrati." Renaissance Quarterly, vol. 33, no. 1, 1980, pp. 33-56.

Spillers, Hortense J. "Mama's Baby, Papa's Maybe: An American Grammar Book." Diacritics, vol. 17, no. 2, 1987, pp. 65-81.

Tougher, Shaun, editor. Eunuchs in Antiquity and Beyond. Classical P of Wales and Duckworth, 2002.

Trevisan, João Silvério. "Tivira, the Man with the Broken Butt: Same-Sex Practices among Brazilian Indians." Lusosex: Gender and Sexuality in the Portuguese-Speaking World, edited by Susan Canty Quinlan and Fernando Arenas, U of Minnesota P, 2002, pp. 3-11.

Vaz, Denise Pires. Ney Matogrosso: um cara meio estranho. Rio Fundo, 1992.

Verneuil, Henri, director. Les amants du Tage. Jacques Gauthier, 1955.

Zurara, Gomes Eanes de. Crónica do descobrimento e conquista da Guiné. Edited by Reis Brasil, Europa-América, 1989. 